\title{
Budoucnost olympismu?
}

\section{Future of Olympism?}

\author{
Josef Dovalil, Antonín Rychtecký \\ Univerzita Karlova, Fakulta tělesné výchovy a sportu, Praha
}

\begin{abstract}
Abstrakt
Stat připomíná stručně pưvodní myšlenky Pierra de Coubertina, které vedly k vytvoření jisté koncepce olympismu (jednoty sportu, výchovy a kultury) a z ní vycházejícího olympijského hnutí i organizace novodobých olympijských her. Olympismus se celosvětově rozšíril a byl akceptován jako základní filosofie novodobého sportu vủbec, tím významně přispěl k povýšení sportu na plnohodnotnou součást kultury. Autoři dokládaji některé symptomy současného často spiše pragmatického sportu a jeho přičiny. Naznačují, že je třeba a že je možné nově formulovat hodnoty, smysl a cíle sportu při zachování a obohacení hlavních olympijských hodnot. Takové zdůvodnění není jen teoretickým požadavkem, je ve vlastním zájmu sportu. Veřejné uznání a podporu si zaslouží sport, jenž je s to uspokojit nejen různé společenské zájmy, ale také kultivovat $v$ duchu humanistických požadavků demokratické společnosti. K tomu může přispět $i$ systém olympijských hodnost, založených na Coubertinově vizi, obohacený dosavadními zkušenostmi a interpretovaný v podmínkách současnosti. Olympismus v nejširším smyslu sportovní praxe i jako filosofie sportu se za těchto podmínek může uplatnit i v podmínkách budoucího společenského vývoje.
\end{abstract}

\begin{abstract}
The article briefly reminds the original ideas of Pierre de Coubertin; they helped him to create a certain conception of Olympism (the unity of sport, education and culture) which became the ground of Olympic Movement and organization of Olympic Games in the New Era. Olympism is nowadays extended in the whole world and being accepted as a basic philosophy of modern sport. It contributes significantly to enhance as constituting a full-value component of culture. The authors present some symptom of modern often very pragmatic sport and the reasons of the changes in it. They indicate the necessity to formulate - in a new situation - the values, purpose and aims of sport in preserving and enriching the principal Olympic values. Such substantiation appears as not only a theoretical requirement, it is in interest of sport itself. Sport deserves not only a public recognition and support since it is satisfying different social interests, but it cultivates members of democratic societies in the sense humanistic desiderata. The system of Olympic values may contribute to those ideas, based on Coubertin visions, enriched by so far obtained experience and interpreted in the contemporary conditions. Olympism in the widest sense of sport practice and as a philosophy of sport may at those conditions find its proper place in the future social development.
\end{abstract}

Klíčová slova: $\quad$ sport, filosofie olympismu, ideové zdroje, hodnoty, olympijské hnutí, olympijské hry, vývoj a prognózy, olympijská interpretace sportu

Keywords: $\quad$ sport, philosophy of Olympism, ideas as source of values, Olympic Movement, Olympic Games, development and prognosis, interpretation of sport

Tato studie vznikla s podporou VZ MŠMT ČR MSM 0021620864 a je věnována 110. výročízaložení Českého olympijského výboru.

\section{ÚVOD}

Novodobý olympismus existuje již víc než sto let, jeho celosvětové rozšíření významně přispělo k povýšení sportu na plnohodnotnou součást společenského života. Vývoj olympismu však nebyl snadný ani 
přímočarý, provázely ho nejrůznější problémy, souhlas i odmítání. Také poslední část cyklu 2005-2008 byla vzhledem k politické konfrontaci obtížnějším obdobím. Sílící negující tendence bylo možné pozorovat v souvislosti s OH 2008 v Pekingu zvláště po událostech v Tibetu na jaře 2008, vše gradovalo při štafetě olympijského ohně. Události a politické vášně, které ji provázely, ohrožovaly nejen hry, ale olympismus vůbec, často se jednalo až o útoky na samotnou podstatu olympismu.

Ani Češi nestáli v olympijském hnutí stranou, od prvních let ho aktivně podporovali. I v českých podmínkách, zvláště v souvislosti s nedávnou kandidaturou Prahy na pořádání $\mathrm{OH}$, se také objevují někdy až agresivní výpady proti olympismu a sportu - např. „Olympijské hry nemají smysl. Nejen v Česku.“ (Steigerwald 2007) nebo „Koho ještě dojímá olympiáda“ (Svoboda 2007). V roce 2009 uplynulo již 110 let od založení Českého olympijského výboru, toto výročí by proto nemělo být pouze připomínkou bohaté historie, ale i príležitostí k úvahám o olympismu současnosti a jeho budoucnosti.

\section{Moderní olympismus}

Ke zrodu novodobého olympismu přispěl, jak známo, podstatnou měrou Pierre de Coubertin. Svoje dílo budoval s velkým obdivem $k$ antice (inspiroval ho především ideál kalokagathie, ekecheirie a samotné řecké $\mathrm{OH}$ ). Ovlivnil ho rovněž anglický sport (systém výchovy sportem, tj. v duchu fair play, osobní odpovědnosti, spojování tělesných i mentálních schopností...). Pokusil se tyto zdroje využít a zobecnit s důrazem na spojení sportu a výchovy. Představy obohacoval a stále zpřesňoval, až vytvořil koncept, později (od r. 1912) označovaný jako „olympismus“. Charakterizoval jej nikoliv jako systém, ale „stav mysli“; později jej interpretoval tak, že stav mysli je součástí „životní filosofie“. Takové vymezení olympismu (Müller 2000; Naul 2008) převzala i současná Olympijská charta:

„Olympismus je životní filozofí, povznášející a vyváženě spojující v jeden celek zdatnost těla, vưle a ducha. Spojením sportu, kultury a výchovy usiluje olympismus o vytvoření způsobu života, založeného na radosti z vynaloženého úsilí, na výchovné hodnotě dobrého př́kladu a na respektování základních univerzálních etických principì."

„Cílem olympismu je zapojit sport do služby harmonického rozvoje člověka scílem vytvořit mírovou společnost, která dbá o zachování lidské dustojnosti."

(Olympijská charta, 2007)

V souladu s touto filosofií bylo vznikající olympijské hnutí spojeno se sportovním soutěžením, uskutečňovaným v duchu rytířství, vzájemné úcty a uznávání. Účast stála výše než vítězství, cenila se vyváženost tělesného, duševního i morálního rozvoje. Byl to pokus na základě zájmu o sport sbližovat různé národy bez ohledu na př́slušnost rasovou, politickou, náboženskou či jinou. Sport měl sloužit i pro reformu výchovy mladé generace. Coubertin chtěl rovněž změnit postoj veřejnosti $\mathrm{k}$ tělesným cvičením. Usiloval o zvýšení společenské prestiže sportu, jeho vnímání jako nezbytné součásti života a jako prostředku $\mathrm{k}$ formování životních postojů a názorů.

Pojem „olympismus“ lze tedy interpretovat jako souhrn filosofických, etických a organizačních principů, které určují obsah olympijského hnutí a vycházejí z všeobecně lidských, kulturních a humanistických hodnot sportu pro rozvoj člověka, upevňování míru, přátelství a vzájemného porozumění.

Coubertin byl natolik realistický, aby viděl, že samotné myšlenky nemají dostatečnou propagační sílu $\mathrm{k}$ tomu, aby se olympismus stal světově známým. K tomu měly sloužit co možná nejpůsobivější slavnosti olympijských her a jejich ceremoniály. Např. Willy Daume, významná osobnost v německém i mezinárodním olympijském výboru, $\mathrm{k}$ tomu později poznamenal: „Olympijské hry jsou mnohem důležitějši než idea, poněvadž činy a výkonnost sportovců znějí mnohem hlasitěji než slova vymezující ideu a jsou také viditelnèjší, avšak bez olympijských ideálu a principů by $\mathrm{OH}$ ztratily svou neopakovatelnou spiritualitu a naopak: olympijské poselství nemůže být šîreno bez OH." (podle Krüger 2007). Sportovci měli být poslové olympijských myšlenek, hry pak událostí, která poselství adresuje do celého světa.

Současně olympijské poselství - a to bývá dodnes mnohdy přehlíženo - nemělo být podle Coubertina svázáno jen s olympijskými hrami. Nemělo se týkat pouze elitních sportovců, nýbrž všech sportovně 
aktivních lidí. Tato demokratická idea, kdy ze sportu nemá být nikdo vyloučen a kdy sport je určen opravdu každému, se promítla později do Olympijské charty, podle níž: „Provozování sportu je lidským právem. Každý jednotlivec musí mít možnost provozovat sport.“(2007). Stejně je sport interpretován i v Evropské chartě sportu (1994).

Přestože olympismus má svůj vlastní teoretický základ, jeho „materiálním“ základem je sport ve své reálné podobě a nemůže být od něho izolován. Bez sportu, tj. sportovních soutěží, pravidel, tréninku, konkrétních aktérů (sportovců, trenérů, funkcionářů), organizátorů, lékařů, diváků, by olympijské ideály a principy ztrácely svůj smysl. Také zdroje a konkrétní podoby olympismu je třeba hledat v každodenním sportu a z něho čerpat pro svůj další rozvoj. Současně však je nutné konstatovat, že olympismus sport výrazně přesahuje, představuje jednotu tří oblastí: sportu, výchovy a kultury. Všechny tři se ovlivňují, prolínají a vytvářejí fenomén, který v komplexu naplňuje primární smysl olympismu.

Jejich vzájemné působení však neprobíhá automaticky. Má-li sport skutečně vytvářet hodnoty v duchu olympijských ideálů, potom musí prostředky výchovy a kultury aktivně využívat. Sport nemůže být bezduchý, bezcharakterní, sobecký, jednostranný. To znamená přes zásadní princip soutěže a konkurence sportu uplatňovat důsledně fair play, porozumění, solidaritu, toleranci, boj proti dopingu. Zprostředkovaně je to i poselství míru, princip rovnosti, negace jakékoliv diskriminace. Olympismus znamená tedy více než jen sport, je také spiritualitou, filosofií sledující a určující zvláštní sportovní koncept, který dovoluje sportu hrát důležitou roli v individuálním rozvoji člověka a být souměřitelný s jinými formami kultury.

V teoretických studiích je současný olympismus charakterizován jako pluralita četných paradigmat a doktrín. Má mnoho dimenzí a aspektů studia, která nelze vystihnout, popsat v jediném celostním aspektu. Tak např. Jegorov $(2000,2001)$ př̀ studiu olympismu rozlišuje:

1. Historickou reflexi, v níž dominuje analýza zdrojů současného olympismu, vývoj neo-olympismu, včetně sportovních poznatků, evoluce hodnot a jejich smyslu.

2. Reflexi opírající se o filosofický výklad sportovní činnosti s aspekty:

a) ontologickými - hledání ontologických základů současného sportu a jeho místa v kultuře,

b) kognitivními - ve vztahu k postavení sportu v současném systému poznatků o člověku a společnosti, v pohledu na sport jako reprezentaci modelů reality, semiotiky aj.,

c) etickými - s kontextem:

- nadsportovním, s důrazem na oprávněnost sportu ve společnosti i v podmínkách komerce, profesionalizace, dopingu, pragmatičnosti, kriminalizace, dehumanizace aj.

- mravního základu sportu - fair play,

d) estetickými - vycházejícími z analýzy vztahů sportu a umění a uměleckých hodnot sportu,

e) axiologickými, zahrnujícími výzkum a studium hodnotových systémů sportu.

3) Paradigmální reflexi s uvědoměním si vzorů a normativů vlastní činnosti a jejich soulad s Olympijskou chartou (výběr olympijských měst, neurčitost aj.).

4) Činnostně-organizační reflexi: výklad forem a organizace současného olympijského sportu, struktury jeho řízení a principy optimalizace vztahů MOV (Mezinárodní olympijský výbor) - MSF (Mezinárodní sportovní federace) - NOV (Národní olympijské výbory) aj.

5) Ideologickou reflexi, která si všímá zjevných a latentních ideologických základů a priorit olympismu.

6) Politickou reflexi, analýzu sportu v systému politické orientace a mezinárodních vztahů.

\section{Sport a jeho proměny}

Ve světě se od dob Coubertina mnohé změnilo, také sport prošel značným vývojem. Jeho podstata však zůstává v zásadě stejná. Člověk musí obstarávat své životní potřeby, musí regenerovat své síly, ale může a postupně i musí prožitkově obohacovat svůj svět. Ve filosofickém smyslu to plní hra jako svobodná lidská činnost, do níž člověk vstupuje spontánně na základě vlastního rozhodnutí. Hra přináší dramatické napětí a jeho řešení, poskytuje hluboký prožitek. Je to činnost přitažlivá, emocionálně nasycená, poskytuje možnost tvořit, sociální kontakt (setkávání člověka s člověkem). To všechno platí i o sportu. Sport je proto ve své podstatě, ve filosofickém smyslu, také hrou. Každý, kdo chce do sportu vstou- 
pit, musí ovšem dodržovat pravidla i respektovat sportovní chování v duchu fair play. Sport dále charakterizuje snaha po dosahování výkonů, které jsou v př́ípadě závodního sportu veřejně demonstrovány v soutěžích. Sport ztělesňuje také jakýsi symbolický boj za stejných podmínek pro všechny. I to může být jedním z dobrodružství, které modernímu člověku jako cosi romantického, vzrušivého a plného napětí zůstalo - vydat ze sebe prostřednictví sportovního výkonu vše. Člověk dnes živočišně nemusí tolik bojovat $\mathrm{v}$ tom pravém smyslu a možná touha po návratu $\mathrm{k}$ dramatu ho dovedla $\mathrm{k}$ tomu, aby si vymyslel sport, jenž mu vrací romantiku a nabízí dostat se na hranu svých schopností a sil. Tuto touhu může člověk jistě naplnit i jinde, avšak sport to nabízí ve velkém. Sport je přitažlivý i divácky, ale divácký zážitek nemůže být a není zdaleka tak silný a nosný, jako aktivní účast.

Sport je nejen zdrojem prožitků, ale ve svých důsledcích také prostředkem rozvoje člověka, trénink má význam jako aktivní činitel zvyšování výkonnosti a zdokonalování člověka. Pro někoho přináší i možnost obživy, stává se i výhodným obchodním artiklem, právě tak jako prestižním činitelem na politické scéně (zvláště úspěšná reprezentace bývá zdrojem národního sebevědomí a vlasteneckého cítění). Pro diváky jsou výkony ve sportu dramatickým zážitkem, mají propagační význam zejména pro děti a mládež. Ve vystupování sportovců je současně skryt velký potenciál ovlivnění (pozitivní za předpokladu, že se prezentují nejen výsledky soutěží, ale i chováním nevybočujícím z uznávaných společenských norem). Sport je jednou z oblastí, umožňující seberealizaci člověka podle jeho dispozic, přitom svět prožitků zde není pouze „konzumován“, ale i „produkován“. Tato spontánní činnost, v níž prožitek je primární, má současně značný dopad za hranice samotného sportu - ve vzdělání a výchově, ekonomický prostor a dopad apod. Sport proto nemá pouze individuální význam, ale má i dimenzi společenskou. Svědčí o tom většinové uznávání širšího mnohostranného přínosu sportu jako součásti národních kultur. Nejen světové a kontinentální organizace (OSN, EU) zahrnují sport do svých programových dokumentů, také státní, regionální i komunální instituce počítají se sportem ve svých plánech rozvoje.

Vstup do nového století probíhá $\mathrm{v}$ atmosféře rozsáhlých společenských změn ve světě, celý širokosáhlý komplex změn a procesů se obvykle označuje souhrnně jako globalizace. Procesy globalizace zasahují přirozeně i do sportu. Vnější podmínky, za nichž mají být dnes hodnoty sportu realizovány, jsou stále obtížnější. Proměny se dotýkají i sportu - jeho organizace, obsahu, hodnot, funkcí, podmínek. Sport ovlivňuje např. změna životního režimu, demokratizace, konzumní orientace společnosti, komercionalizace, medializace, vzájemné pronikání kultur, demografický vývoj, globalizace aj. Většinou nejde o vlivy působící jen ve sportu, ale ve sportu nacházejí často př́íznivé uplatnění. Také pro sport je určující vývoj společenský. O tom, jaký sport je a bude, mohou proto rozhodnout jeho aktéři pouze do určité míry, nebot' sport je také ovlivňován politikou, ekonomikou a mediální sférou. Jeho podoba je určována veřejnou poptávkou, motivovanou nejrůznějšími cíli. Zasahuje to však někdy do samotné podstaty sportu a ovlivňuje jeho původní poslání. Zdá se, že některé vlivy v posledních desetiletích nabývají na síle a nejsou ojedinělé hlasy poukazující na ohrožení sportu, jeho samotné podstaty: porušování fair play, doping, násilí ve sportu a kolem něho, nacionalismus, přehnaná komercionalizace, korupce, levná medializace, kult hvězd... Takové negativní aspekty jsou také asociovány se sportem. Ve většině případů nejsou ohrožující faktory pro sport zcela specifické, ale obecně existující jevy, které ve sportu nalezly příznivé podmínky k útoku. Proto je někdy obtížné při prosazování a organizování sportu rozvíjet původní vizi sportu. Lze dokonce říci, že sport je v jistém smyslu zpochybňován natolik, že se ve veřejnosti objevuje až averze ke sportu.

\section{Mediální obraz sportu}

Sportovní dění dnes zprostředkovávají media všech druhů na úrovni místní, regionální, státní i mezinárodní. Tato skutečnost výrazně napomáhá rozvoji a šíření sportu, jeho popularitě, znalostem o jednotlivých i méně známých odvětvích, přináší řadu prožitků. Má ovšem i některé stinné stránky.

Mediální pozornost se omezuje téměř výhradně na vrcholový sport. Jeho atraktivita přitahuje pozornost příznivců a zároveň i odpůrců na celém světě. Díky mimořádným ekonomickým podmínkám, mocným sponzorům, masivní reklamě a zejména velké podpoře sdělovacích prostředků (hlavně televize) má ve společnosti vysoké prestižní postavení. 
Ve vyhraněné podobě pouze vrcholný výkon znamená úspěch. Ten je doprovázen slávou, obdivem, publicitou a penězi, prohra často odsouzením, kritikou. Pro mnoho sportovců (ale i trenérů a funkcionářů) nastává dilema, co udělat, aby se vyhnuli neúspěchu, aby dále zvyšovali výkonnost, aby minimalizovali selhání a mohli zůstat v zorném poli sportovní slávy. Za této situace bývá velmi svůdné sáhnout k nedovoleným prostředkům - dopingu, účelovému porušování pravidel (podvody, faulování, simulování, uplácení, podvádění). Cítí-li se jedinec jako součást obchodní atmosféry, nemusí se mu potom zdát nic neobvyklého prodat vítězství za patřičnou sumu peněz. Mediální svět občas bohužel vytváří mínění, že je možné, ba žádoucí podvádět. Úspěch za jakoukoli cenu se prostě vyplácí, je třeba o něj usilovat a ty, kdo se nad tím pohoršují, odkázat do role mravokárců.

Mediální pozornosti se často dostává negativním aspektům sportu. Většinou se z vlastních komerčních důvodů (co největší prodejnosti či sledovanosti) vyzdvihuje hlavně to negativní, aniž by byly v patřičných proporcích současně osvětlovány a oceňovány jeho pozitivní rysy. Zvláště módními a tzv. žádanými se stávají kauzy, ve většině př́padů nafouklé banality. V souvislosti s tím se nekriticky a falešně rozšiřuje mínění, že nepodaří-li se z jakékoliv události udělat za každou cenu kauzu, nikdo o ni neprojeví zájem. Také toto vede $\mathrm{k}$ relativnímu ohrožení sportu a jeho skutečné hodnoty zůstávají v pozadí jako méně důležité.

Medializace má i další důsledky - pod jejím vlivem dochází - opět z komerčních důvodů - ve vrcholovém sportu k předimenzování kalendáře soutěží, úpravě pravidel, volbě data a hodiny soutěží, někdy $\mathrm{v}$ neprospěch samotného sportu.

Další aspekt vlivu sdělovacích prostředků se týká mediální prezentace sportovců. Fabrikovaný „kult hvězd“ jednostranně soustředuje pozornost na jejich finanční př́ijmy, přestupy, aféry a skandály jejich veřejného i soukromého života apod. Téměř utajena bývá jejich příprava k výkonům, jejich úsilí, odříkání, překonávání mnoha překážek, rizik (např. zranění) apod. Je tu i nerovnost mezi sporty: rozdíl mezi velmi dobře placenými sportovci a těmi sportovci, kteří mají vynikající výkony, vyžadující také dlouhodobou a náročnou př́pravu, ale ve sportech, které nejsou tak atraktivní (zvláště pro televizní přenos), a kteři jsou oceňováni minimálně. Sportovci bývají přitom často idolem především pro mladé lidi (tabulka 1). Pokud se přitom zdůrazňuje především ekonomická úspěšnost, nelze se divit, že chování idolů je často napodobováno bez ohledu na to, zda se jedná o chování sociálně přijatelné či nikoliv. Přitom veřejně prezentovaný model sportovního chování často vytváří jistou mravní normu lidského jednání nejen ve sportu.

Tabulka 1. Vzory a ideály české mládeže (Sofres Factum 2002)

\begin{tabular}{|l|c|}
\hline Identifikované vzory a ideály & $\%$ \\
\hline Sportovci & 45 \\
\hline Ekologické iniciativy & 24 \\
\hline Herci & 22 \\
\hline Hvězdy popu & 18 \\
\hline Modelky, modely & 12 \\
\hline Politici & 7 \\
\hline Náboženští vůdci & 4 \\
\hline Nikdo & 34 \\
\hline
\end{tabular}

Mediální pozornost omezená téměř výhradně na vrcholový sport způsobuje, že sport jako celek přestává být někdy vnímán pozitivně, ztrácí svůj širší kredit prospěšné činnosti. Většina českých medií se nepokouší podat hlubší, skutečný obraz sportu s jeho mnohostranným individuálním i společenským významem. Spíše se fabrikuje jeho umělý mediální obraz a stírá se vědomě hranice mezi významem skutečným a významem zdánlivým, virtuálním.

Do klasického (olympijského) chápání sportu, jemuž se oprávněně připisuje výrazný humanistický smysl, media vstupují často tak, že to zasahuje do samotné podstaty sportu a ovlivňuje jeho původní 
poslání. Zatímco v něm jsou hodnoty sportovního výkonu spojovány s dlouhodobým rozvojem sportovce (jeho těla, psychiky i morálky), pod vlivem hlavně vrcholového sportu se vyzdvihují jiná kriteria. Dochází tak k zásadnímu posunu chápání hodnoty sportovního výkonu od původního prostředku zdokonalování až k výkonu jako hlavnímu cíli tréninku, který přináší úspěch sportovce, a ten pak i finanční prospěch.

\section{Diferenciace sportu}

Působením medií se nejvíce viditelný stal sport vrcholový. Nicméně právě mediálně akcentovaným pohledem pouze na vrcholovou úroveň nemusí být sport jako celek vždy vnímán pozitivně (je mu také přisuzována role při podněcování násilí, agresivity, podvádění, poškozování zdraví) a veřejnost tímto pohledem posuzuje i ostatní úrovně sportu, které mají z celospolečenského hlediska stejnou důležitost. Přes často umělé zviditelňování nelze zapomínat, že vrcholový a profesionální sport není jediným reprezentantem sportu, který zahrnuje širší spektrum hodnot (odreagování, obohacení prožitkové sféry, rozvíjení zdatnosti, prevence civilizačních chorob, sociální kontakt atd.).

Vědomě je proto třeba sport diferencovat $\mathrm{v}$ jeho podstatě, smyslu i hodnotách podle věku, úrovně tělesných i jiných předpokladů a také zájmu i motivace na sport dětí a mládeže, sport rekreační a kondiční, sport soutěžní, sport seniorů, sport zdravotně postižených, sport extrémně rizikový, profesionální sport, př́padně diváckýsport.

Mnohé koncepty - např. Evropská charta sportu (1992), Bílá kniha o sportu Evropské komise (2007) i další - se v tomto smyslu obracejí $\mathrm{k}$ vládním i nevládním organizacím s výzvou k úzké spolupráci ve snaze chápat a prosazovat sport jako významný faktor lidského rozvoje v celé jeho komplexnosti.

\section{Olympijské hry}

Olympijské hry zůstávají světovou sportovní soutěží číslo jedna, v současnosti jsou nejvíce medializovanou světovou událostí. Reflektují je mladí i staří, sportovci i nesportovci. V dosavadní historii doznaly nejen velkého rozmachu a světové popularity, ale současně došlo $\mathrm{k}$ nárůstu počtu účastníků, nároků na jejich organizaci a ke zvýšení nákladů. Přitom už v roce 1911 Pierre de Coubertin (1977) prohlásil, že „by byla velká škoda, kdyby náklady, často přhnaně vysoké během nedávných Olympiád, v budoucnosti odradily některé země od kandidatury na pořádání olympijských her."

Např. podle údajů MOV se OH v Soulu v roce 1988 zúčastnilo 159 NOV, na programu bylo 237 soutěží, v Sydney 2000 už to bylo 199 NOV a 300 soutěží, v Athénách 2004 pak 201 NOV a 301 soutěží, v Pekingu 2008 celkem 204 NOV a 302 soutěží. V Sydney bylo prodáno 6,7 miliónů vstupenek, bylo př́tomno na 20000 pracovníků medií a podle odhadu 3,7 miliardy televizních diváků sledovalo přenosy soutěží, z Atén 3,9 miliardy, z Pekingu podle globálního marketingového výzkumu od Sports Marketing Surveys 4,4 miliardy - nejsledovanější hry v historii viděly dvě třetiny světové populace, př́tomno bylo 16000 plně akreditovaných novinářů a asi 35000 neakreditovaných... Počet všech akreditovaných osob ve srovnání Los Angeles 1984 a Sydney 2000 se zdvojnásobil ze 100000 na 200 000, pokud jde o ZOH za stejné období se akreditace zvýšily z 35000 na 90000.

$\mathrm{OH}$ jsou trvale v centru pozornosti olympijského hnutí - jejich rozsah, organizace, zajištění atd. V MOV se jimi zabývá především speciální studijní komise pro olympijské hry. Např. na 115. zasedání MOV v Praze 2003 předložila 119 bodů návrhů a úprav.

Text doporučuje, jak komplexně kontrolovat a snížit složitost příprav her, jejich provedení i náklady. Cílem je přitom zachovat hry takové, aby zůstaly hlavním a jedinečným setkáním sportovců celého světa, tzn. zachovat podmínky, které dovolují sportovcům dosahovat nejlepších výsledků a zajistit specifickou atmosféru her, a současně umožnit médiím pokrývat soutěže a informovat o nich svět. MOV musí bdít nad tím, aby obyvatelé pořadatelských měst měli prospěch ze zařízení, infrastruktury, prostředí a zkušeností. Větší neznamená ještě lepší a nadbytek výdajů nezaručuje nutně lepší kvalitu.

Hlavní závěry z kongresu:

- Olympijské hry se přidělují hostitelským městům. 
- Trvání soutěží nesmí překročit 16 dní.

- Maximální počet sportovců 10500 a 28 sportů.

- Jako zimní sporty mohou být uznávány pouze sporty, které jsou prováděny na sněhu nebo ledě.

- Minimalizovat náklady a maximalizovat využití soutěžních a tréninkových zařízení i dalších objektů, zaručit jejich plné využití pokud jde o čas, prostor i služby (např̀ otevření vesnice před zahájením her, tiskového střediska).

- Organizační výbor her musí přijmout účinné postupy na podnikatelském poli s cílem zlepšit řízení her a koordinaci prací tak, aby bylo co nejlépe využito zdrojů.

- Vydat vhodné směrnice a najít prostřredky k udržení celkového počtu osob, akreditovaných na hrách.

- Skončit s růstem cen, vyvolávaným porovnáváním s předchozími a jinými většími akcemi. Nabídka služeb by měla zůstat na rozumné úrovni a být přizpůsobena reálným potřebám (např. výstavba vesnice, střediska pro média, restaurace, dopravy, personálu a bezpečnostní služby).

- Použít existujících zkušeností a znalostí z programu řízení olympijských her, které vedly ke snížení personálu a poradenských nákladů.

- Vyhnout se předčasnému najímání početného personálu a překotnému plánování příliš malou skupinou expertů.

- Časově vymezit dodání olympijského ohně do pořadatelské země tak, aby nebylo překročeno 100 dní od zapálení olympijské štafety v Olympii.

- Přizpůsobit počet dobrovolníků skutečným potřebám.

- Zvýšit počet publikací elektronického formátu a omezit, pokud to bude možné, formát tištěný.

Existují snahy uvedená doporučení postupně realizovat.

Poslední kapitolou v olympijském hnutí byly XXIX. olympijské hry v čínském Pekingu. Už samotné rozhodnutí MOV o přidělení her v roce 2001 vyvolalo velmi protichůdné postoje: Na jedné straně některé nevládní organizace a mnozí novináři oponovali, že pořádání her Číně z politických důvodů být svěřeno nemělo, na druhé straně bylo vyjadřováno přesvědčení ( $\mathrm{MOV}$, řada $\mathrm{NOV}$ ), že $\mathrm{OH}$ mají budovat mosty a nikoli zdi a že právě světový sportovní svátek povede $\mathrm{k}$ „otevření “ Číny, k proniknutí demokratických a svobodných idejí a olympiáda se stane katalyzátorem změn v zemi. Uplatňování neomezené vlády komunistické strany bylo demokratickým světem oprávněně kritizováno (nerespektování lidských práv, otázka Tibetu, potlačování náboženských hnutí, kontrola médií apod.). K zesílení této fronty došlo na jaře po událostech v Tibetu a vše sublimovalo do událostí spojených se štafetou olympijského ohně. Zprostředkovaně se téma olympismu spojovalo i se svobodou projevu účastníků $\mathrm{OH}$, objevovaly se i hlasy volající po bojkotu her. Terčem pochybností se stalo pravidlo 51.3 Olympijské charty, zakazující na olympijských sportovištích a v dalších olympijských prostorách politickou, náboženskou, rasovou a jinou propagandu. OH v Pekingu 2008 byly tak výrazně politizovány. Také některá česká média se soustředila na otázky porušování lidských práv Čínou, možnosti bojkotu olympiády a neúčasti českých sportovců. (ČOV se těmito otázkami několikrát zabýval, opakovaně odmítl tvrzení některých politiků, že brání sportovcům ve svobodném vyjadřování názorů, a současně odsoudil porušování lidských práv kdekoli ve světě.)

Samotné $\mathrm{OH}$ byly připraveny a organizovány na vysoké úrovni. Účastníci her byli obyvateli Pekingu vřele přijati, zájem o olympijské soutěže i sportovce byl velký. V olympijské vesnici a na sportovištích nezazněla za celou dobu žádná veřejně proklamovaná politická témata. Soudržnost, kooperaci a přátelské soužití 204 NOV lze považovat za přínos světového sportu a olympismu pro možná řešení různých konfliktů.

I mnohé z minulých her nebyly bez problémů: v Londýně 1948 stavěli sportoviště němečtí zajatci, hry v Mexiku 1968 nezastavily demonstrace studentů proti využití her jako manifestace politické korektnosti vlády, střelba proti nim zanechala desítky mrtvých, v Mnichově došlo k vraždám izraelských sportovců arabskými teroristy př́mo během olympijských dnů, Salt Lake 2002 bylo poznamenáno korupčními skandály atd. Olympijské instituce (MOV, NOV) nejsou politické organizace. Listina základních práv a svobod OSN je daleko silnější dokument než Olympijská charta. Otázky přesahující horizont sportu - 
tedy lidská práva a nimi související zákony a jejich dodržování - jsou především v kompetenci vládních a mezinárodních vládních organizací, olympismus takovou moc nemá.

Vnímání a následně působení olympijských idejí a her je přirozeně diferencované. Potvrzují to i výsledky našeho vlastního šetření (Rychtecký a Dovalil 2009) u středoškolské mládeže 18-19 let, studentů FTVS a českých olympioniků. Co je s $\mathrm{OH}$ nejvíce asociováno, dokumentuje obr. 1. Pozorovali jsme širší asociační spektrum u olympioniků. Osobní zkušenost a dlouhodobá stáž ve sportu v širší míře dokumentuje i vztah k hodnotám olympismu. Mládež často redukuje olympijské hnutí na OH, sporty, sportovce a sportovní soutěže. Pouze malá část $\mathrm{z}$ nich ho spojuje se sociálně emotivní zkušeností a dalšími pozitivními principy, jakými jsou mír, fair play atd., sílí pravděpodobně asociace s negativními znaky, kterými jsou dle nich komercialismus, extrémně přeceněná role peněz a médií. To naznačuje, že se oslabuje informace, že na počátku olympijského hnutí to byly především výchovné cíle a motivy, které v minulosti otevřely cestu $\mathrm{k}$ současné pozici $\mathrm{OH}$ ve světě.

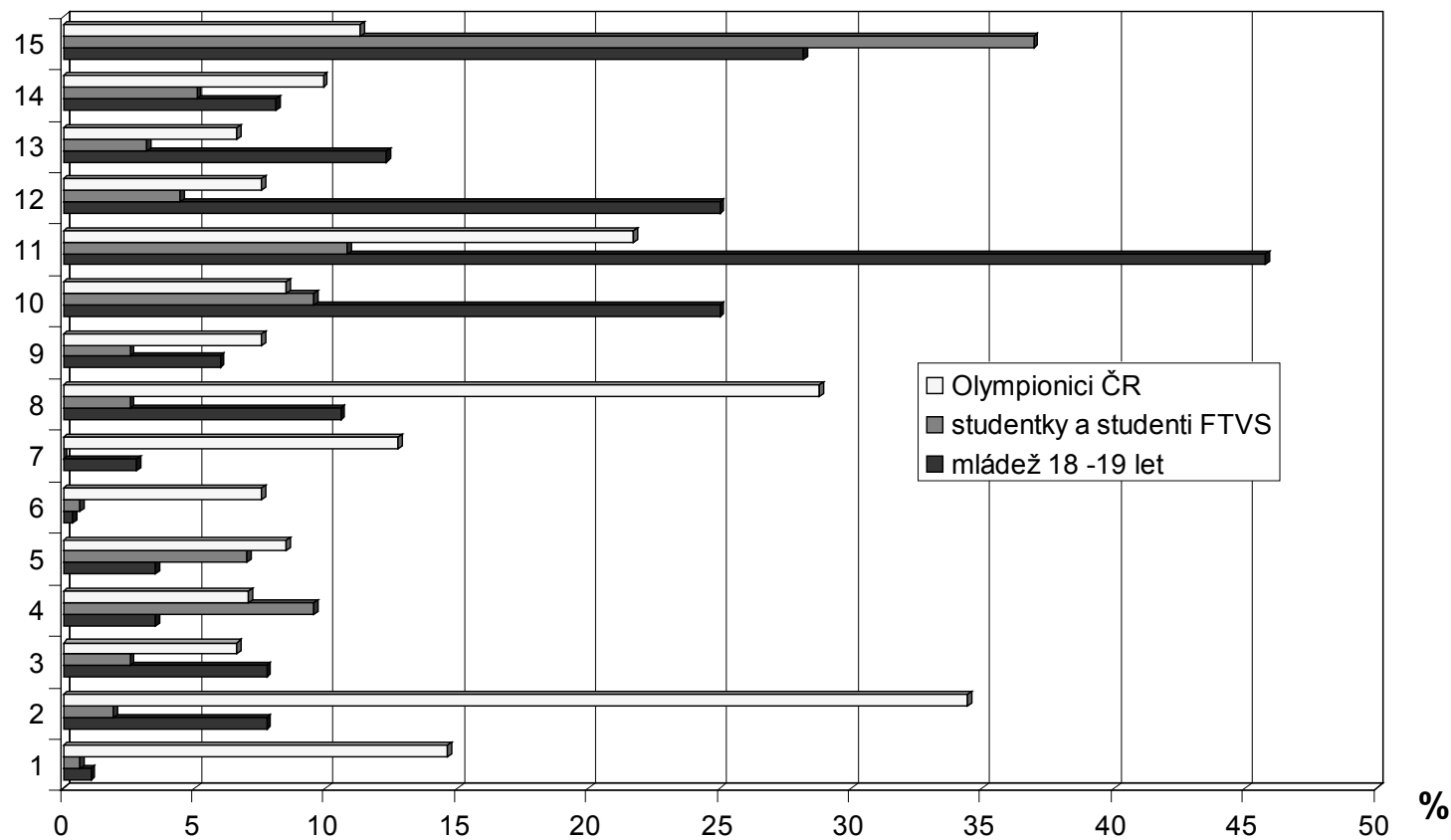

Obr. 1 Volné asociace vybavené ve vztahu k olympijským hrám

Legenda: 1. individuální aspekt, 2. sociálně emotivní zkušenost, 3. drogy, doping, 4. fair play, 5. mír, 6. účast víc než vítězství, 7. další morální hodnoty, 8. mezinárodní porozumění, 9. historické kořeny, 10. olympijské symboly, 11. soutěžení, 12. druhy sportů/sportovci, 13. komercionalizace/peníze, 14. komercionalizace/masmédia, 15. další odpovědi + neodpověděli

OH poskytují velký prostor a možnosti k širší propagaci myšlenek olympismu a demonstraci olympijských tradic, principů a symbolů. Jsou a nepochybně i v budoucnosti zůstanou nejvýznamnějším světovým festivalem sportu, kultury, umění, míru a přátelství. Pokud se nezpronevěří svému poslání, dokáží hluboce, racionálně i emocionálně působit na světovou veřejnost. Je nepochybné, že OH vytvářejí také trvalé sportovní, výchovné i kulturní hodnoty, úspěšně přispívají k demokratizaci mezinárodní politiky, vztahy mezi národy pomáhají eliminovat rasovou i sociální nesnášenlivost, podněcují umění. $\mathrm{OH}$ nejsou jedním ze sportovních podniků. Mají specifický duchovní obsah, hlubší propojení na výchovu, kulturu, humanismus, internacionalismus a universalismus. Jsou něčím víc než součtem šampionátů. Olympionik je nejen soutěžící, ale je i sportovním a kulturním vyslancem své země. Neprosadí-li se, resp. zmizí-li takové pojetí, $\mathrm{OH}$ se přemění na bezduchou show. 


\section{Budoucnost olympismu?}

Zdá se, že mnohé rysy současného sportu nenaplňují původní olympijskou vizi jejich zakladatele. Není nic nového na tom, že mezi realitou a ideály existují rozpory, to věděl už sám Coubertin. Vnější podmínky, za nichž mají být dnes hodnoty olympismu realizovány, jsou jiné a sport odráží rovněž jejich proměny: Politické, ekonomické a společenské souvislosti dnešního sportu olympismus ovlivňují.

Sport má samozřejmě sám v sobě prvek růstu sportovní výkonnosti. Čím výrazněji se prosazuje jeden z hlavních olympijských principů - výše, rychleji, silněji (často ve velmi vulgarizovaném výkladu výkon za každou cenu) - a čím více se objevují např̀. marketingové vstupy vnějších zájemců, tím větší je v mnoha sportovních odvětvích závislost na těch, kteří do sportu investují své prostředky. Spolu s hraničními nároky na výkon roste i nebezpečí, že se sportovci dostanou do pokušení např. získat výhody tak, že se uchylují k unfair chování v nejširším smyslu. Olympijské hnutí s těmito obtížně řešitelnými problémy permanentně bojuje.

Jistý ústup idejí olympismu způsobuje také, jak jsme uvedli výše, vliv médií, která často zcela nekriticky obracejí pozornost veřejnosti na nepodstatné aspekty sportu (přestupy, aféry aj.). Akcentování senzačních a zdánlivě atraktivních témat odvádí veřejnost od vlastních hodnot sportu, a navíc sport takovou jednostranností i poškozuje. Snaha o změnu takových př́stupů by proto také měla být součástí sportu, jeho propagace i organizace.

Setkáváme se často s názorem, že např. výkonnostní růst sportovců je především záležitosti finanční. To reprezentuje zásadní posun chápání hodnoty sportovního výkonu od původního prostředku, jímž se člověk kultivuje, až k výkonu jako hlavního cíle tréninku, který přináší úspěch sportovce a ten pak i finanční prospěch. Tento kauzální řetězec výkon - úspěch - peníze však popírá širší, hlavní a původní smysl sportu. Vrcholné výkony ve sportu, umění, vědě i v ostatních lidských činnostech přímo s penězi spojeny nejsou. Peníze jako externí pobídky nemohou nahradit silnou vnitřní potřebu k sebepřekonávání. Sportovec, který potřebu k vlastnímu sebepřekonání ztratil nebo ji př̌kryl vnějšími materiálními stimuly, může jen obtížně dosahovat rekordních výkonů.

Už v antice byl sport považován za důležitou formu kultury společnosti. Reprezentoval také způsob její organizace, respektování norem, hodnot, zkrátka civilizační úroveň. Ani dnes se tento obraz nezměnil. Sport je navzdory negujícím postojům nadále společensky považován za důležitou formu kulturního výrazu, reflektující sociální vývoj i úroveň rozvoje civilizace.

Sport má v sobě mnohostranný potenciál, řadu společensky žádoucích možností či příležitostí. Ovšem pouze tehdy, pokud se zakládá na uznávaných pozitivních hodnotách. Otázka smyslu a zdůvodnění olympismu není ovšem jen ideovou otázkou, je ve vlastním zájmu sportu. Veřejné uznání a politickou podporu si zaslouží pouze přitažlivý, náročný a přitom slušný sport, jenž uspokojuje různé individuální zájmy, ale také přispívá ke kultivaci člověka v duchu humanistických idejí demokratické společnosti.

$\mathrm{V}$ tomto směru je žádoucí usměrňovat další vývoj olympijského hnutí do budoucna. To se však zdá téměř nemožné pouze $\mathrm{v}$ rámci fenoménu sportu, není-li to vlastní celé společnosti. Uznávání a šiření principů olympismu by $\mathrm{v}$ tom však mohlo významně pomoci. Znamená to znovu se obracet $\mathrm{k}$ základním hodnotám olympismu, propagovat a prosazovat je ve sportu. Sport může být generátorem těchto společensky prospěšných hodnot, může aktualizovat pozitivní postoje za jistých podmínek, tj. vezmou-li se v úvahu, a brzdí se vliv faktorů, které sport ohrožují.

Sport a olympismus je nadále mnohostranně oceňován, nabízí příležitosti k osobnímu růstu, seberealizaci prostřednictvím sportovních výkonů. Existuje dostatek důkazů (např. Svoboda, 2000) o tom, že ve sportu (zejména dětí a mládeže) převažují ještě hodnoty, spojené s dobrovolností, nadšením, obětavostí trenérů a funkcionářů.

Sport dneška už není sportem, z jakého vycházel Coubertin. Změnil se, stal se světově rozšířeným fenoménem a do jisté míry univerzálním „vzorem kultury“. Také z tohoto důvodu je nasnadě, že ne všechny tradiční hodnoty olympijského sportu mohly zůstat nezměněny. Některé z nich však platí a měly by platit stále. Nejdůležitějším zůstává respektování důstojnosti a vážnosti člověka a uznání jeho osobnosti. Ve sportu je nutno i v budoucnosti vidět sportovní aktivitu ve spojitosti s čestným jednáním a práátelstvím. To platí pro všechny, kteří sport provozují. 
Předvídat budoucí vývoj olympismu není snadné. Výhledy proto mohou být pouze subjektivní a přibližné. Zatím nejrozsáhlejší je v tomto směru studie Milštejna (2000), který v letech 1991-1999 uskutečnil na 500 interview se sportovci, trenéry, funkcionáři MOV, NOV, mezinárodních sportovních federací a dalšími odborníky olympismu z 80 zemí, mezi nimiž byli účastníci her 1936-96 a sportovci 40 odvětví. Principiálně lze názory expertů a vyvozované tendence představit v několika bodech závěrů:

- Většina dotázaných si myslí, že $\mathrm{OH}$ budou věčné jako součást moderní kultury i civilizace, přestože svět je a bude zmítán konflikty, pohromami přírodními nebo sociálně-ekonomickými, hry budou ve své existenci pokračovat a rozvíjet se.

- Nevelký počet dotazovaných předvídá, že hry se zničí, budou-li se rozvíjet dále pouze podle dnešního modelu komercionalizace sportu, pokud bude vítězit doping a porušováno pravidlo rovnosti podmínek a nebude-li ctěn princip fair play. Přesto, i mezi experty, kteří říkají, že konec $\mathrm{OH}$ se blíží, panuje názor, že hry se znovuzrodí, avšak v nových formách a modelech organizace.

- Globalizace olympismu a olympijského hnutí bude poškozovat sport v rozvojových zemích Asie, Afriky a Latinské Ameriky.

- Dají se očekávat změny v evropských národních i mezinárodních strukturách klubů a národních reprezentací v důsledků rostoucí migrace sportovců ze zemí Afriky, Jižní Ameriky, zemí bývalého SSSR a zemí východní Evropy.

- Rychlý vývoj nových netradičních sportů bude přitahovat rostoucí počet mladých, zvláště v industrializovaných zemích. $\mathrm{V}$ těchto sportech se také budou ustavovat mezinárodní federace a budou vyvíjet tlak na zařazení do programu $\mathrm{OH}$.

- Výběr kandidátských měst řeší MOV nově. Má se za to, že jde o začátek revolučních změn v řízení MOV.

- Bude třeba nových forem organizace a řízení komplexu mezinárodních soutěží, v důsledku globalizace se zvýší počet regionálních i světových soutěží.

- Dojde k harmonizaci rozvoje sportu vrcholového a sportu pro všechny podle modelů, které již existují v Norsku, Finsku, Německu, Australii, Kanadě a jinde.

- Zvětší se „vzdálenosti“ mezi aktivním a diváckým sportem.

- Zvýší se role mezinárodních sportovních federací v olympijském hnutí, jednak půjde o vliv finanční, mohou se však i objevit tendence odstoupit z olympijského hnutí.

- Dojde k posílení role NOV.

Ve své historii prošlo olympijské hnutí řadou vývojových etap, které nastolovaly mnoho otázek, které bylo a stále je třeba řešit (např. podoba olympijských her, finanční zajištění činnosti olympijského hnutí a šíření olympijských hodnot). Pokud se podaří hry chápat ne pouze jako událost, nabízející napínavou zábavu, ale i jako symbol určité trvalejší myšlenky, tak lze do budoucnosti hledět optimisticky. Zájem - aktivních sportovců, ale i diváků, ekonomiky, médií, politiky a v neposlední řadě i četných kandidátských měst - neupadá. $\mathrm{K}$ tomu je samozřejmě nutné vymezit, zpřesňovat a obnovovat pravidla $\mathrm{v}$ duchu olympismu, která jsou a budou jejich základem. Zdá se, že i olympijské hnutí se tak může úspěšně podílet na současné světové globalizaci. A může to být právě olympijská ideologie, která byla, je a lze předpokládat, že i do budoucna bude zdrojem užitečných hodnot díky své univerzálnosti a srozumitelnosti.

Uplatnění hlavních idejí olympismu nejen ve sportu, ale i v celospolečenském měřítku se stane v budoucnosti pravděpodobně ještě naléhavější než dosud, jejich humanistický obsah sport společensky povyšuje:

- Sport v olympijském pojetí znamená společenské kulturní hnutí, posilující v celosvětovém měřítku integraci světa.

- Představuje významnou možnost kultivace člověka a společnosti v duchu humanismu a demokracie, přispívá k upevňování solidarity, přátelství a spolupráce s cílem budování mírového světa.

- Hlavním prostředkem $\mathrm{k}$ realizaci i propagaci těchto cílů jsou nejrůznější formy sportovních aktivit, podporující zájmy i rozvoj účastníků v jednotě jejich tělesných, duševních, morálních a sociálních aspektů, včetně pravidelného konání olympijských her. Jde o veřejnou aktivitu (soutěže, trénink, slavnosti a další formy), která tvoří součást národních kultur. 
- Účast ve sportu jako univerzální a přitažlivé činnosti by měla být pro všechny „právem“ bez jakékoliv diskriminace národnostní, rasové, náboženské či sociální se zvláštním důrazem na účast mládeže.

- Podmínkou k realizaci všech záměrů je vytváření vhodných podmínek z prostředků států, občanských sdružení a dalších subjektů.

- Sportovní aktivity musejí být zajištovány odpovídající organizací a v širokém smyslu i odborným vedením.

Mnohaletý vývoj prokázal principiální životaschopnost a nadčasovost olympismu a růst prestiže olympijského hnutí. Olympijské hnutí se rozšírilo se po celém světě, olympismus byl postupně akceptován jako základní filosofie novodobého sportu vůbec, přihlásila se $\mathrm{k}$ němu většina sportů a jejich federací, tím významně přispěl k povýšení sportu na plnohodnotnou součást společenského života.

Podíváme-li se zpět, vidíme, že Coubertin považoval projekt olympismu za součást procesu modernizace světa. K ní patří i sport. Předjímal i ústřední problém moderního světa: Jak je možné dosáhnout, aby pro individuální život a sociální soužití byly zakotveny hodnoty a principy, důležité pro život, jednání a zkušenosti mnoha lidí, a aby bylo možné je upevňovat, zveřejňovat a co nejvíce světově rozšiřovat. Byla to vize. Coubertin věřil, že je to také sport ve spojení s filosofí́ olympismu, které k tomu mohou přispět. Tato vize ani ve světle problémů dnešního i budoucího světa neztratila nic na svém významu. Olympismus v nejširším smyslu sportovní praxe i jako filosofie sportu je schopný se uplatnit i v podmínkách budoucího vývoje společnosti.

Nic však neplyne samo od sebe, celý dosavadní vývoj i současnost ukazují, že o ideje a principy olympismu je třeba bojovat. Nejen ti, kteři sport provozují, ale také sportovní instituce, národní a mezinárodní organizace a v neposlední řadě i MOV nesou odpovědnost za uchování olympijských hodnot, myšlenky fair play, rovnosti príležitostí a vstrícnosti, za zachování respektu a tolerance, a tím za rozvoj eticky založené olympijské sportovní kultury: pěstovat sport jako kulturní statek se spolehlivou a závaznou morálkou. Naplnění potenciálu sportu závisí na tom, zda bude postaven na společensky pozitivních hodnotách a jim odpovídající prezentaci sportu. K tomu může přispívat systém olympijských hodnot, založených na vizi Coubertina, obohacený dosavadními zkušenostmi a interpretovaný v podmínkách současnosti i budoucnosti. Je proto důležité oceňovat a prosazovat hodnoty olympijského sportu a široce je nadále propagovat. Tato cesta ovšem byla, je a bude plná konfliktů, její schůdnost však může a musí usnadnit důsledná olympijská výchova. Podpora olympijské interpretace sportu je dnes i pro budoucnost aktuální.

\section{Literatura:}

BUCHANAN, I., MALLON, B. Historical Dictionary of the Olympic Movement. London: Lanham, 1995. CALLEBAT, L. P. Pierre de Coubertin. Paris, 1988.

COUBERTIN, P. Pédagogie sportive. Paris: Les éditions G. Cres et Cie, 1922.

COUBERTIN, P. Olympijské pamèti. Praha: Olympia, 1977.

ČERNUŠÁK, V. Niektoré súčasné problémy mezinárodného olympijského hnutia. Praha: Olympia, 1987. ČERNUŠÁK, V. Smerovanie olympizmu na začiatku 21. storočia. In:Zborník. Materiály z činnosti Slovenskej olympijskej akadémie z rokov 2003-2005. Bratislava: Slovenský olympijský výbor, 2007, s. 87-91.

DOVALIL, J. a kol. Olympismus. Praha: Olympia, 2004.

DOVALIL, J., CHOUTKA, M., SVOBODA, B. Pohledy na současný sport. Česká kinantropologie 9, 2005, č. 1, s. 45-60.

DOVALIL, J. O smyslu olympijských her a sportu vůbec. Olympijská knihovnička č. 43. Praha: Český olympijský výbor, 2008.

DURRY, J. Pierre de Coubertin. The Visionary. Paris, 1996.

Evolution du mouvement olympique 1980-1998. Lausanne: COI, 1998.

Evropská charta sportu. 1994.

GLESK, P., MERICA, M. Olympismus. Bratislava: Slovenská technická univerzita, 1997.

GREXA, J. Olympijská výchova. Bratislava: Slovenský olympijský výbor, 2006. 
GREXA, J. Historický odkaz olympizmu očami súčasnosti. In: Zborník. Materiály z činnosti Slovenskej olympijskej akadémie z rokov 2003-2005. Bratislava: Slovenský olympijský výbor, 2007, s. 91-96.

HODAŇ, B. Olympismus a současný svět. Česká kinantropologie, 1997, 1, s. 83-90.

HODAŇ, B. Sociokulturní kinantropologie I. Brno: Masarykova univerzita, 2006.

JEGOROV, A.G. Filosofskoje značenie sovremennogo olimpizma. Teor. Prakt. Fiz. Kult., 2001, 7, s. 18-26.

JEGOROV, A. G., JEFREMENKOV, K. N., PETLJEVANYJ, G. F. Mnogoobrazije olimpizma i dinamika olimpijskogo obrazovanija. Teor. Prakt. Fiz. Kult., 2000, 9, s. 39-42.

Kolektiv: The International Olympic Committee. One Hundred Years. I.-III. IOC. Lausanne: Edipresse Imprimeries Réunies, 1997.

KRÜGER, M. The Evolution of Olympic Pedagogy and its Place in the Modern Educational System. 9th International Session for Directors of National Olympic Academy. Ancient Olympia: International Olympic Academy, 2007, s. 8-15.

MILŠTEJN, O. A. The Olympic Movement and Sport in the 21st Century: the Prognostic by Olympic Oracles. In: International Olympic Academy. Fourtieth Session 2000: Olympic Games, Athletes and Spectators. Ancient Olympia: IOC, 2001, s. 122-129.

MÜLlER, N. (ed.) Pierre de Coubertin. Olympism. Selected Writings. Lausanne: International Olympic Committee, 2000.

Olympijská charta. Praha: ČOV, 2007.

RYCHTECKÝ, A., DOVALIL, J., TILINGER, P. Vnímání olympijských her a olympijských principů mládeží a olympioniky České republiky. Česká kinantropologie 13, 2009, 3, s. 18-38.

SEKOT, A. Sportovní aktivity: nejednotné hodnotové směřování. In: Tělesná kultura. Olomouc: FTK 2003, 1.

STEIGERWALD, K. Olympijské hry nemají smysl. Nejen v Česku. Mladá fronta DNES, 13. 12. 2007.

SVOBODA, A. Koho ještě dojímá olympiáda. Mladá fronta DNES, 29. 9. 2007.

SVOBODA, B. Pedagogika sportu. Praha: Karolinum, 2000.

SVOBODA, B. Top Sport at its Commercial Stage. Acta Universitatis Carolinae Kinanthropologica. 1998, 1, s. 5-15.

www.olympic.org 